\title{
Lactobacillus amylovorus, a New Starch-Hydrolyzing Species from Cattle Waste-Corn Fermentations
}

\author{
L. K. NAKAMURA
}

Northern Regional Research Center, Agricultural Research, Science and Education Administration, U.S. Department of Agriculture, Peoria, Illinois 61604

Several starch-hydrolyzing strains of Lactobacillus Beijerinck 1901 were isolated from cattle waste-corn fermentations. The isolates were facultatively anaerobic, gram-positive, nonmotile, nonsporeforming, rod-shaped organisms that grew singly and in short chains, produced lactic acid and small amounts of acetic acid but no gas from glucose, and did not exhibit oxidase-, catalase-, or nitrate-reducing activities. Growth occurred at $45^{\circ} \mathrm{C}$ but not at $15^{\circ} \mathrm{C}$. DL-Lactic acid was synthesized from glucose. An extracellular amylolytic enzyme was formed. The organisms fermented amygdalin, cellobiose, esculin, fructose, galactose, glucose, maltose, mannose, salicin, starch, sucrose, and trehalose. Some strains fermented mannitol and lactose. Arabinose, gluconate, melezitose, melibiose, raffinose, rhamnose, ribose, and xylose were not fermented. The average guanine-plus-cytosine content of the deoxyribonucleic acid was 40.4 mol\%. Reassociation values of $15 \%$ or less were obtained with the deoxyribonucleic acids of the starch hydrolyzers and those of the type strains of Lactobacillus acidophilus (Moro) Hansen and Mocquot 1970; Lactobacillus jensenii Gasser, Mandel, and Rogosa 1970; and Lactobacillus leichmanii (Henneberg) Bergey et al. 1923. The new species was differentiated from the three recognized species on the basis of starch fermentation, vitamin requirements, guanine-plus-cytosine contents, and stereoisomerism of lactic acid produced. It was concluded that these organisms represent strains of a hitherto unrecognized species for which the name Lactobacillus amylovorus is proposed. The type strain of $L$. amylovorus is NRRL B-4540.

Studies at the Northern Regional Research Center demonstrated that lactobacilli are the predominant bacteria involved in cattle wastecorn fermentations (12). The principal Lactobacillus species identified were $L$. buchneri, $L$. fermentum, L. plantarum, L. casei, and L. delbrueckii. By the use of LBS (Lactobacillus selection) agar (29) enriched with $1 \%$ corn starch, it was revealed that of the presumed lactobacilli enumerated some were capable of hydrolyzing starch (13). Because active starch metabolism is a characteristic not commonly exhibited by lactobacilli, the following questions concerning the taxonomic position of these starch hydrolyzers were raised. (i) Were these organisms unusual strains of presently recognized Lactobacillus species? (ii) Were they strains of hitherto unrecognized Lactobacillus species? (iii) Were they other starch-hydrolyzing bacteria capable of growing on LBS agar?

The present study was undertaken to characterize the starch hydrolyzers and to determine their taxonomic status. The results indicate that the organisms represented strains of a new $L a c$ tobacillus species.

\section{MATERIALS AND METHODS}

Bacterial strains. Twelve starch-hydrolyzing isolates from cattle waste-corn fermentations (13) were received from $G$. Hrubant of the Northern Regional Research Center. Used as reference organisms in deoxyribonucleic acid (DNA) reassociation studies were Lactobacillus acidophilus NRRL B-1858 and B-2092, Lactobacillus leichmanii NRRL B-735, and Lactobacillus jensenii NRRL B-4550. Strains NRRL B1858 , B-735, and B-4550 are the type strains of their respective species. In addition, strain NRRL B-4437, the type strain of Lactobacillus amylophilus Nakamura (20), was also used as a reference. These microorganisms are maintained by the Agricultural Research Culture Collection at the Northern Regional Research Center. Working stocks were grown for $48 \mathrm{~h}$ on de Man, Rogosa, and Sharpe (MRS) agar (5) stabs at $37^{\circ} \mathrm{C}$ and stored at $4^{\circ} \mathrm{C}$.

Characterization tests. The organisms were characterized according to the methods published by Rogosa et al. (31), Rogosa and Sharpe (30), and Sharpe et al. (36). According to Sharpe et al. (36), a useful modification of MRS medium for conducting the tests is a formulation containing, in 1 liter of distilled water: Difco proteose peptone no. $3,10.0 \mathrm{~g}$; yeast extract, 5.0 $\mathrm{g}$; Tween $80,1.0 \mathrm{~g}$; glucose, $10.0 \mathrm{~g}$; ammonium citrate, $2.0 \mathrm{~g}$; sodium acetate, $5.0 \mathrm{~g} ; \mathrm{MgSO}_{4} \cdot 7 \mathrm{H}_{2} \mathrm{O}, 0.1 \mathrm{~g} ; \mathrm{MnSO}_{4}$. 
$\mathrm{H}_{2} \mathrm{O}, 0.05 \mathrm{~g}$; and $\mathrm{Na}_{2} \mathrm{HPO}_{4}, 2.0$ g. Nitrate reduction, growth in $8 \% \mathrm{NaCl}$, susceptibility to sodium dodecyl sulfate, effect of incubation temperature, and effect of initial $\mathrm{pH}$ were determined in this medium. Nitrate reduction was also determined in indole-nitrite medium which contained: Trypticase (BBL Microbiology Systems), $20.0 \mathrm{~g} ; \mathrm{Na}_{2} \mathrm{HPO}_{4}, 2.0 \mathrm{~g}$; glucose, $1.0 \mathrm{~g}$; and $\mathrm{KNO}_{3}, 1.0 \mathrm{~g}$; in 1 liter of distilled water. According to Rogosa (24), some lactobacilli reduced nitrate in this medium.

To study the effect of incubation temperature, preincubated sterile culture medium in screw-capped test tubes was inoculated and incubated in a water bath adjusted to the desired temperature. The capacity to grow under anaerobic conditions was determined in freshly prepared broth in screw-capped test tubes. The medium was cooled, inoculated, covered with a 3cm layer of sterile mineral oil, sealed tightly, and incubated at $37^{\circ} \mathrm{C}$. For all tests, the inoculum was 1 drop of culture grown for $24 \mathrm{~h}$ at $37^{\circ} \mathrm{C}$ in modified MRS broth. For determining oxidase (38) and catalase activities, and for morphological studies, the organisms were cultured on the modified medium solidified with $1.5 \%$ agar.

Glucose fermentation was determined in the modified MRS broth to which was added $0.0016 \%$ bromocresol purple. Other fermentation tests required the replacement of glucose with the appropriate sugar. Pentoses were sterilized separately by filtration and added to the sterile broth. Durham tubes were used when glucose or gluconate was the test substrate. Inoculum for the fermentation tests was grown for 24 $h$ in modified MRS broth at $37^{\circ} \mathrm{C}$. The cells were collected by centrifugation at $4^{\circ} \mathrm{C}$, washed with sterile $0.85 \%$ saline, and resuspended in sterile saline. One drop of inoculum per tube was used.

A gas chromatographic procedure (2) was used to analyze qualitatively the acids present in the cell-free liquors of cultures grown for 4 days in deep-liver broth (10) at $37^{\circ} \mathrm{C}$. Deep-liver broth was an acetate-free medium that supported good growth of the organism. This procedure was capable of detecting acetic acid at concentrations as low as $10^{-4} \mathrm{M}$.

Vitamin requirements. Vitamin requirements were studied by the method of Ford et al. (7) and Rogosa et al. (28). Commercially prepared pancreatintreated casein (Casitone, vitamin-free) was used. Treatment with a modification of the method of Roberts and Snell (23) prepared the Casitone for use; each adsorption with 1.5 times the prescribed amount of Darco G-60 charcoal was repeated three times.

Determination of the optical activity and quantity of lactic acid. Cultures were grown for $\mathbf{4 8}$ $\mathrm{h}$ at $37^{\circ} \mathrm{C}$ in 1 liter of modified MRS broth which contained either $1 \%$ glucose or soluble starch. To prepare samples for assay, $15 \mathrm{ml}$ of culture liquor was centrifuged at $10,000 \times g$ for $15 \mathrm{~min}$ at $4^{\circ} \mathrm{C}$, and the resulting supernatant was deproteinized by titration with $\mathrm{NaOH}$ to $\mathrm{pH} 7.6$ in the presence of $2.5 \% \mathrm{ZnSO}_{4}$ (16). The precipitate was removed by centrifugation at $4^{\circ} \mathrm{C}$, and the supernatant was analyzed. Beef heart L-(+)-lactic dehydrogenase (EC 1.1.1.27) and L. leichmanii D-(-)-lactic dehydrogenase (EC 1.1.1.28) were used for assessing the stereoisomerism of the lactic acid produced by the starch-hydrolyzing isolates. (Both enzymes were purchased from the Boehringer Mannheim Corp., New York, N.Y.) The method used was that of Latorre-Guzman et al. (16). The assay mixture consisted of $0.1 \mathrm{ml}$ of enzyme $(50 \mu \mathrm{g})$ solution, $2.0 \mathrm{ml}$ of $\mathrm{pH} 9.5$ glycine-hydrazine sulfate buffer $(7.5 \%$ glycine, $5.2 \%$ hydrazine sulfate, $0.2 \%$ sodium ethylenediaminetetraacetate, and $4.0 \% \mathrm{NaOH}$ ), $0.1 \mathrm{ml}$ of 56 $\mathrm{mM}$ nicotinamide adenine dinucleotide solution, 0.1 $\mathrm{ml}$ of appropriately diluted sample, and $0.7 \mathrm{ml}$ of distilled water. Uninoculated broths with and without L-(+)- and D-(-)-lithium lactate were used as controls. The above-mentioned enzymes showed specificity for their respective substrates. Substrate utilization, indicated by nicotinamide adenine dinucleotide reduction, was monitored at $340 \mathrm{~nm}$ in a Unicam dual-beam recording spectrophotometer.

For quantitative determinations, the amounts of enzyme and nicotinamide adenine dinucleotide were increased to $200 \mu \mathrm{g}$ and $7.5 \mu \mathrm{mol}$, respectively, to ensure total oxidation of the lactic acid. The reaction mixture was incubated for $45 \mathrm{~min}$ at $37^{\circ} \mathrm{C}$, and the increase in optical density at $340 \mathrm{~nm}$ was recorded. An extinction coefficient value of $6.22 \times 10^{6} \mathrm{M}^{-1} \mathrm{~cm}^{-1}$ was used to calculate the amount of nicotinamide adenine dinucleotide reduced. The amount of lactic acid equaled this calculated amount.

DNA base composition and reassociation. DNA was extracted and purified by a modification of Marmur's method (18). The modification involved the use of hydroxyapatite (Bio-Gel HTP, Bio-Rad Laboratories) chromatography (17) to produce highly purified DNA preparations. The purity and quality of each DNA preparation were checked by monitoring the absorbancy ratio at $260 / 280 \mathrm{~nm}$ (1.8 to 1.9$)$ and at $260 / 230 \mathrm{~nm}$ (2.0 to 2.3) (according to Marmur [18]) and by the melting curves, which include hyperchromicity values from 38 to $40 \%$ (19).

The guanine-plus-cytosine $(\mathrm{G}+\mathrm{C})$ content of the DNA was estimated by the buoyant density method (32). Buoyant density of the DNA was measured by $\mathrm{CsCl}$ density gradient centrifugation in a Beckman model E ultracentrifuge. "Micrococcus lysodeikticus" (not on the Approved Lists of Bacterial Names, 1980 [37]) DNA served as an internal standard.

In preparation for renaturation studies, native double-stranded DNA was sheared by two passages through a French pressure cell at $10,000 \mathrm{lb} / \mathrm{in}^{2}$. After filtration through a $0.45-\mu \mathrm{m}$-pore size Millipore membrane, the sheared DNA solution was dialyzed exhaustively against $0.001 \mathrm{M}$ EDTA solution containing $5 \mathrm{ml}$ of SSC (0.15 M NaCl-0.015 M trisodium citrate, pH 7.0) per liter. After dialysis, the DNA solution was freeze dried. The dried material was redissolved in 2 $\mathrm{ml}$ of double-distilled water.

The kinetics of DNA renaturation was measured in reaction mixtures that contained $0.3 \mathrm{ml}$ of $10 \times \mathrm{SSC}$, $0.2 \mathrm{ml}$ of dimethyl sulfoxide, approximately $75 \mu \mathrm{g}$ of DNA, and double-distilled water to bring the volume to $1 \mathrm{ml}$. In reaction mixtures containing two different DNAs, the concentrations (about $37.5 \mu \mathrm{g}$ ) of the nucleic acids were adjusted to differ by no more than $0.15 \mu \mathrm{g}$. The reaction mixtures were placed in $0.4-\mathrm{ml}$ quartz cuvettes that were sealed with Teflon-lined 
stoppers. Denaturation and renaturation were effected and monitored in a Gilford UV-VIS Thermal Analyzer System. A denaturation temperature of $90^{\circ} \mathrm{C}$ was obtained rapidly and held for $10 \mathrm{~min}$ after the hyperchromic shift at $260 \mathrm{~nm}$. Subsequently, the temperature was lowered rapidly to $25^{\circ} \mathrm{C}$ below $T_{m}$; the optical density at this point was taken to represent $0 \%$ renaturation (although some undoubtedly occurs). For these studies, the $T_{m}$ values were determined in the presence of $3 \times$ SSC and $20 \%$ dimethyl sulfoxide. The absorbance change at $260 \mathrm{~nm}$ was monitored until the DNA was more than $50 \%$ reassociated. All determinations were repeated three times. Percent reassociation was calculated by the equation given by Seidler and Mandel (35).

Extracellular amylolytic activity. The organisms were grown in MRS broth modified to contain $1 \%$ soluble starch in place of glucose; $\mathrm{CaCO}_{3}(1 \%)$ was also added. After $48 \mathrm{~h}$ of growth at $37^{\circ} \mathrm{C}$, the cells were removed after centrifugation at $10,000 \times \mathrm{g}$ for $15 \mathrm{~min}$ at $4^{\circ} \mathrm{C}$. The supernatant $(25 \mathrm{ml})$ was dialyzed overnight at $4^{\circ} \mathrm{C}$ against several changes of distilled water.

The amylolytic activity in the supernatant was determined in reaction mixtures that contained: $2 \%$ soluble starch (Pfansteil) in $0.002 \mathrm{M}$ phosphate buffer (pH 6.0), $25 \mathrm{ml}$; cell-free supernatant, $12.5 \mathrm{ml}$; and distilled water, $12.5 \mathrm{ml}$. The mixture was incubated at $37^{\circ} \mathrm{C}$, and 5 -ml samples were taken at indicated time intervals. After heating for $10 \mathrm{~min}$ at $100^{\circ} \mathrm{C}, 1 \mathrm{ml}$ of the sample was diluted and assayed for reducing sugar by the alkaline ferricyanide method (11). Residual starch was estimated on the basis of the iodine-starch complex color. Assay mixtures contained $1 \mathrm{ml}$ of appropriately diluted sample, $0.1 \mathrm{ml}$ of iodine solution $\left(0.2 \mathrm{~g}\right.$ of $\mathrm{I}_{2}$ and $2.0 \mathrm{~g}$ of $\mathrm{KI}$ in $100 \mathrm{ml}$ of distilled water), and sufficient distilled water to bring the volume to 10 $\mathrm{ml}$. Absorbance was read at $590 \mathrm{~nm}$ in a Unicam dual- beam recording spectrophotometer. A linear relationship between concentration and absorbance was observed when starch levels in the sample ranged from 0.2 to $1.0 \mathrm{mg}$.

An undiluted portion of the sample $(2 \mathrm{ml})$ was mixed with $8 \mathrm{ml}$ of methanol. After filtration to remove the precipitate, the filtrate was evaporated to dryness. The dried material was dissolved in $0.2 \mathrm{ml}$ of distilled water, and the oligosaccharide (low molecular weight) content was assayed by chromatography on a $\mu$-Bondapak $\mathrm{NH}_{2}$ column ( $30 \mathrm{~cm}$ by $4 \mathrm{~mm}$ ID) in a Waters Associates ALC-100 high-pressure liquid chromatography unit. Samples were eluted with acetonitrile-distilled water $(65: 35)$ solvent at a constant flow rate of $2 \mathrm{ml} / \mathrm{min}$. Malto-oligosaccharide standards ranging from D-glucose to maltononaose served as markers for calibrating the elution positions. Maltotriose and higher malto-oligosaccharide standards were prepared by the procedure of Taylor and Whelan (39).

\section{RESULTS}

Morphology and physiology. All twelve isolates were gram-positive, nonsporeforming, nonmotile rods that existed singly and in short chains (Fig. 1). The average cell measured 1.0 by 3.0 to $5.0 \mu \mathrm{m}$. Colonies on LBS and modified MRS agar had entire edges and were white, smooth, convex, and opaque. Clear zones of hydrolysis surrounded colonies that grew on LBScorn starch agar. The physiological properties of the starch-hydrolyzing isolates were: growth at $45^{\circ} \mathrm{C}$ but not at $15^{\circ} \mathrm{C}$; no catalase-, oxidase-, or nitrate-reducing activities; no gas from glucose or gluconate; and both $\mathrm{L}-(+)$ - and $\mathrm{D}-(-)$-lactic acids and small amounts of acetic acid produced

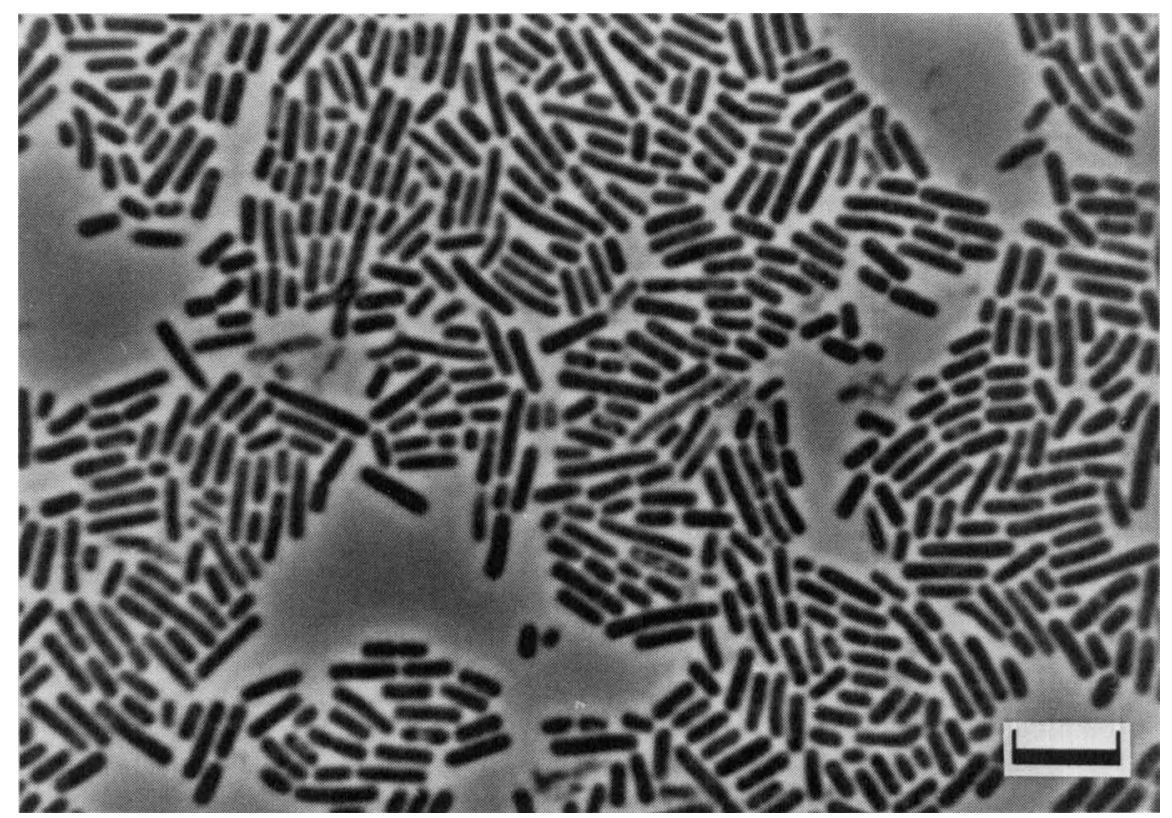

FIG. 1. Phase-contrast photomicrograph of living cells of the starch-hydrolyzing bacteria. Bar, $5 \mu \mathrm{m}$. 
from glucose. Organisms with these characteristics could be tentatively classified as members of Lactobacillus (27). Other characteristics included susceptibility to $0.4 \%$ sodium dodecyl sulfate and $8 \% \mathrm{NaCl}$. The organisms grew under anaerobic conditions and at initial $\mathrm{pH}$ values that ranged from 4.5 to 8.0. Furthermore, growth failed in MRS medium that was devoid of a metabolizable sugar.

Fermentation characteristics. As is recorded in Table 1, the starch-hydrolyzing strains actively fermented cellobiose, fructose, galactose, glucose, maltose, mannose, starch, sucrose, and trehalose. Amygdalin, esculin, and salicin were attacked slowly. The isolates can be separated into four subgroups on the basis of slow mannitol and lactose fermentations. Group 1 organisms, represented by strain B-4538, fermented both mannitol and lactose; group 2 organisms, represented by strain B-4549, fermented lactose; group 3 organisms, represented by strain B-4542, attacked mannitol; and group 4 strains, represented by strain B- 4540 , fermented neither sugar. Group 4 organisms were the most frequently encountered type. Arabinose, gluconate, melezitose, melibiose, raffinose,

TABLE 1. Carbohydrate fermentation by starchhydrolyzing isolates

\begin{tabular}{lcccc}
\hline \multirow{2}{*}{ Substrate } & \multicolumn{4}{c}{ Strain $^{a}$} \\
\cline { 2 - 5 } & B-4538 & B-4549 & B-4542 & B4540 \\
\hline Amygdalin & $(+)$ & $(+)$ & $(+)$ & $(+)$ \\
Arabinose & - & - & - & - \\
Cellobiose & + & + & + & + \\
Esculin & $(+)$ & $(+)$ & $(+)$ & $(+)$ \\
Fructose & + & + & + & + \\
Galactose & + & + & + & + \\
Gluconate & - & - & - & - \\
Glucose (acid) & + & + & + & + \\
Glucose (gas) & - & - & - & - \\
Lactose & $(+)$ & $(+)$ & - & - \\
Maltose & + & + & + & + \\
Mannitol & $(+)$ & - & $(+)$ & - \\
Mannose & + & + & + & + \\
Melezitose & - & - & - & - \\
Melibiose & - & - & - & - \\
Raffinose & - & - & - & - \\
Rhamnose & - & - & - & - \\
Ribose & - & - & - & - \\
Salicin & $(+)$ & $(+)$ & $(+)$ & $(+)$ \\
Sorbitol & - & - & - & - \\
Starch & + & + & + & + \\
Sucrose & + & + & + & + \\
Trehalose & + & + & + & + \\
Xylose & - & - & - & - \\
\hline
\end{tabular}

${ }^{a}$ Symbols: + , Acid produced in 1 to 3 days; $(+)$, acid produced in 4 or more days; - , acid not produced in 7 days.
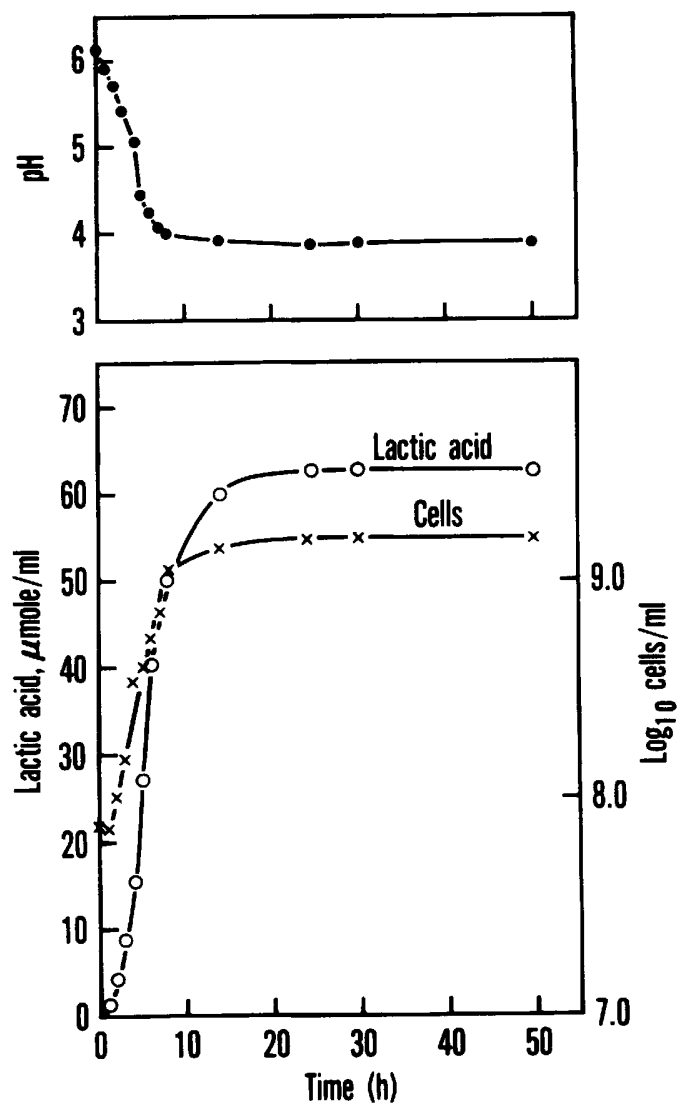

Fig. 2. Growth of and lactic acid production by strain B-4540 in MRS broth containing soluble starch as the energy source. Cell counts estimated with a Petroff-Hausser cell counter.

rhamnose, ribose, sorbitol, and xylose were not fermented by the isolates.

A detailed study of a typical starch (soluble) fermentation is illustrated in Fig. 2. Exponential growth commenced after a lag period of $1 \mathrm{~h}$ and continued for about $9 \mathrm{~h}$. Concomitant with the onset of rapid growth was a rapid production of lactic acid and related decrease of the culture $\mathrm{pH}$ value. Maximum acid production of approximately $65 \mu \mathrm{mol} / \mathrm{ml}$ was achieved in about $15 \mathrm{~h}$. Measurements by the iodine method revealed that $85 \%$ of the starch was utilized at $15 \mathrm{~h}$. Since complete hyrolysis of $10 \mathrm{~g}$ of starch would theoretically yield $11.11 \mathrm{~g}$ of glucose, the equivalent amount of glucose fermented was $9.4 \mathrm{~g}$ or 0.052 mol. The amount of glucose converted to lactic acid was $0.5 \times 0.065 \mathrm{~mol}$. Therefore, $62.5 \%$ $(0.032 / 0.052)$ of the glucose was fermented to lactic acid.

Lactic and acetic acids were the only acids detected by gas chromatographic analyses of the 
fermentation liquors. Estimates indicated that acetic acid constituted 5 to $10 \%$ of the two-acid mixture.

Vitamin requirements. The isolates required pantothenic acid, folic acid, nicotinic acid, and riboflavin for growth. With respect to vitamin requirements, the starch hydrolyzers were similar to L. acidophilus (28).

DNA base composition. The buoyant densities of the DNAs from the new isolates ranged from 1.6994 to $1.6996 \mathrm{~g} / \mathrm{cm}^{3}$, which corresponded to $\mathrm{G}+\mathrm{C}$ values ranging from 40.2 to $40.4 \mathrm{~mol} \%$. These values fall within the range reported for DNA of the Lactobacillus species subgrouped as thermobacteria $(25,27)$.

DNA reassociation. As shown in Table 2, reassociation values ranging from 5 to $15 \%$ were obtained with the DNAs of the starch hydrolyzers and those of $L$. acidophilus B-1858 and B2092, L. jensenii B-4550, L. leichmanii B-735, and L. amylophilus B-4437. Control experiments in the present work and in other studies (14) indicated that distinct but related species of a genus exhibited DNA reassociation values of $20 \%$ or less.

High reassociation values of $85 \%$ or more were measured for DNAs from the four starch-hydrolyzing isolates; similarly high reassociation values were found for DNA-DNA interaction for two strains of $L$. acidophilus. Studies have shown that organisms with reassociation values exceeding $70 \%$ belong to the same species (14).

Extracellular amylolytic activity. As illustrated in Fig. 3, treatment of soluble starch with cell-free culture liquor of strain B-4540 caused rapid decrease of the starch-iodine complex color and a concomitant increase of reducing sugar.
Chromatographic analysis of a 7-h sample of the reaction mixture revealed that maltose, maltotriose, maltotetraose, and maltopentaose constituted the bulk of the oligosaccharide produced (Fig. 4). No oligosaccharides were observed in the 0-h sample.

These evidences demonstrated clearly the presence of amylolytic enzyme activity in the culture liquor of strain B-4540. Starch-degrading activity was detected in the culture liquor of all 12 isolates.

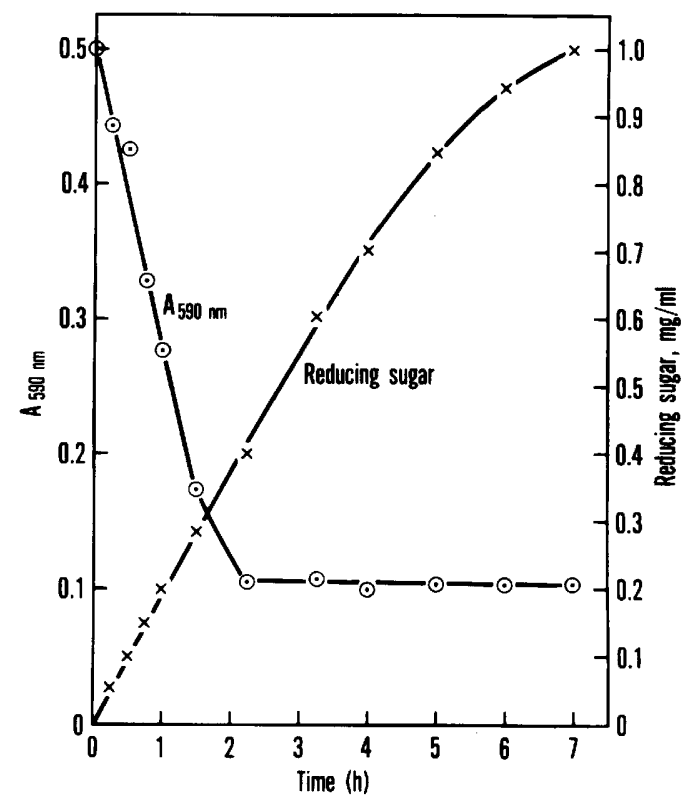

FIG. 3. Treatment of soluble starch with cell-free culture liquor of strain $B-4540$.

TABLE 2. DNA relatedness among the starch hydrolyzers and reference Lactobacillus strains

\begin{tabular}{|c|c|c|c|c|c|c|c|c|}
\hline \multirow[b]{2}{*}{ Strains } & \multicolumn{8}{|c|}{ Reassociation $\left(\% \pm \mathrm{SD}^{a}\right)$ to DNA from: } \\
\hline & $\begin{array}{c}\mathrm{SH}^{b} \\
\text { NRRL } \\
\mathrm{B}-4540\end{array}$ & $\begin{array}{c}\text { SH } \\
\text { NRRL } \\
\text { B-4542 }\end{array}$ & $\begin{array}{c}\text { SH } \\
\text { NRRL } \\
\text { B-4549 }\end{array}$ & $\begin{array}{c}\text { L. leich- } \\
\text { manii } \\
\text { NRRL } \\
\text { B-735 }\end{array}$ & $\begin{array}{c}\text { L. acido- } \\
\text { philus } \\
\text { NRRL } \\
\text { B-1858 }\end{array}$ & $\begin{array}{c}\text { L. acido- } \\
\text { philus } \\
\text { NRRL } \\
\text { B-2092 }\end{array}$ & $\begin{array}{l}\text { L. jensenii } \\
\text { NRRL } \\
\text { B-4550 }\end{array}$ & $\begin{array}{c}\text { L. amylo- } \\
\text { philus } \\
\text { NRRL } \\
\text { B-4437 }\end{array}$ \\
\hline \multicolumn{9}{|l|}{ Starch hydrolyzers } \\
\hline NRRL B-4538 & $90 \pm 1$ & $88 \pm 2$ & $93 \pm 1$ & $14 \pm 4$ & $15 \pm 2$ & $10 \pm 3$ & $9 \pm 2$ & $11 \pm 3$ \\
\hline NRRL B-4540 & & $97 \pm 3$ & $96 \pm 3$ & $13 \pm 3$ & $15 \pm 3$ & $11 \pm 2$ & $10 \pm 3$ & $9 \pm 2$ \\
\hline NRRL B-4542 & & & $93 \pm 2$ & $11 \pm 3$ & $13 \pm 4$ & $5 \pm 4$ & $11 \pm 2$ & $9 \pm 1$ \\
\hline NRRL B-4549 & & & & $10 \pm 2$ & $13 \pm 2$ & $14 \pm 1$ & $12 \pm 3$ & $11 \pm 3$ \\
\hline \multicolumn{9}{|l|}{ L. leichmanii } \\
\hline NRRL B-735 & & & & & $16 \pm 2$ & $9 \pm 1$ & $6 \pm 1$ & $\mathrm{ND}^{c}$ \\
\hline \multicolumn{9}{|l|}{ L. acidophilus } \\
\hline NRRL B-1858 & & & & & & $85 \pm 2$ & $8 \pm 1$ & ND \\
\hline NRRL B-2092 & & & & & & & $9 \pm 2$ & ND \\
\hline
\end{tabular}

${ }^{a} \mathrm{SD}$, Standard deviation.

${ }^{b} \mathrm{SH}$, Starch hydrolyzer.

${ }^{c} \mathrm{ND}$, Not done. 


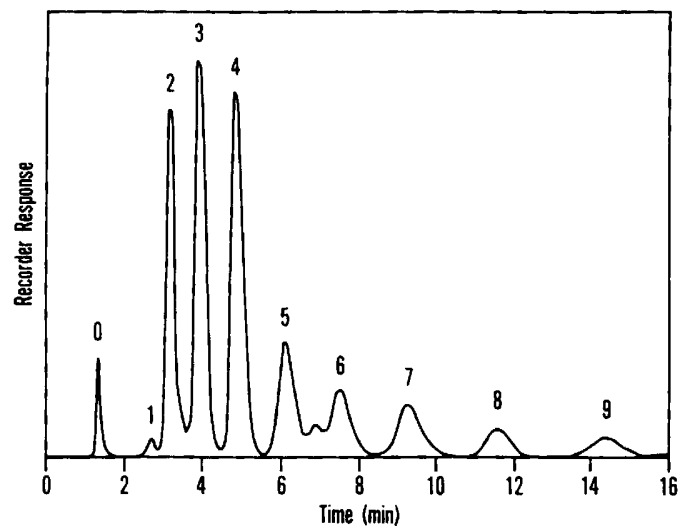

Fig. 4. Oligosaccharides produced by 7-h hydrol$y$ sis of soluble starch with strain B-4540 culture broth. Sugars identified are: 1 , glucose; 2 , maltose; 3 , maltotriose; 4 , maltotetraose; 5 , maltopentaose; 6 , maltohexaose; 7, maltoheptaose; 8, maltooctaose; and 9, maltononaose. Peak marked 0 is the solvent front.

\section{DISCUSSION}

The morphological and physiological characteristics of the starch-hydrolyzing bacteria isolated from cattle waste-corn fermentations suggest that these organisms belong to the family Lactobacillaceae Winslow et al. (1). The organisms are facultatively anaerobic, gram-positive, nonmotile, nonsporeforming, rod-shaped cells that grow in short chains, produce large quantities of lactic acid and small amounts of acetic acid but no gas from glucose, have requirements for a number of vitamins, and do not exhibit oxidase-, catalase-, or nitrate-reducing activities. These features are typical of the homofermentative Lactobacillus species $(27,30)$ and are clearly different from those of the other genera of the family, namely, Listeria Pirie 1940, Erysipelothrix Rosenbach 1909, and Caryophanon Peshkoff 1939; the latter are coccoidal, tend to form filaments, and are aerobic, respectively $(9$, $33,34)$.

The ability to grow at $15^{\circ} \mathrm{C}$ is a criterion that differentiates between the homofermentative lactobacilli subgrouped as streptobacteria and thermobacteria $(27,30)$. Whereas the streptobacteria grow at $15^{\circ} \mathrm{C}$ and even at 5 to $7^{\circ} \mathrm{C}$, thermobacteria do not; streptobacteria may or may not grow at $45^{\circ} \mathrm{C}$, and the thermobacteria always do. Furthermore, most streptobacteria ferment gluconate to acid and gas, and ribose to acid; thermobacteria do not ferment these substrates $(25,30)$. On the basis of the results obtained, the new isolates can be classified as thermobacteria.

In general, the sugar fermentation patterns of the starch hydrolyzers are very similar to those of $L$. acidophilus, L. leichmanii, and L. jensenii (27). However, the ability of all of the new isolates to ferment starch strongly and of some to ferment mannitol slowly distinguishes them from the three recognized species. Moreover, the $\mathrm{G}+\mathrm{C}$ contents of $L$. leichmanii $(50.8 \mathrm{~mol} \%)$ and $L$. jensenii (36.1 mol\%), their vitamin requirements, and their synthesis of $\mathrm{D}-(-)$-lactic acid definitely differentiate them from the new isolates, which have $\mathrm{G}+\mathrm{C}$ contents of about 40.0 mol\% (Table 3). Finally, the low relatedness of their DNAs (Table 2) indicates that the new isolates are genetically unrelated to the type strains of $L$. leichmanii and $L$. jensenii.

In addition to the overall similarity of their carbohydrate fermentation patterns, the new isolates and $L$. acidophilus also have in common the ability to synthesize DL-lactic acid and the requirement for riboflavin, nicotinic acid, folic acid, and panthothenic acid for growth (Table 3 ). In spite of these phenotypic similarities, the differences in the $\mathrm{G}+\mathrm{C}$ contents of their DNAs and especially the low DNA relatedness (Table 2 ) indicate strongly that the new isolates and $L$. acidophilus are separate species.

A starch-hydrolyzing lactobacillus isolated from swine waste-corn fermentations has been proposed as a new species, $L$. amylophilus (20). As shown in Table 3, the synthesis of $\mathrm{L}-(+)$ instead of DL-lactic acid, growth at $15^{\circ} \mathrm{C}$ but not at $45^{\circ} \mathrm{C}, \mathrm{a} \mathrm{G}+\mathrm{C}$ content of $44.4 \mathrm{~mol} \%$ compared to $40.4 \mathrm{~mol} \%$, and the inability to ferment lactose, mannitol, sucrose, and trehalose differentiate L. amylophilus from the new isolates. The low relatedness of their DNAs (see Table 2) further substantiates that these two starch-hydrolyzing organisms are not highly related genetically and hence belong to different species.

The new isolates are distinctly different from the lactic acid bacteria of the family Streptococcaceae Deibel and Seeley 1974 (3). Aerococcus Williams et al. 1953 and Gemella Berger 1960 demonstrate poor anaerobic growth $(6,22)$; $\mathrm{Leu}$ conostoc van Tieghem 1878 is heterofermentative (8); and Streptococcus Rosenbach 1884 and Pediococcus Balcke 1884 exhibit definite coccoidal morphology $(4,15)$.

Also, classification of the new isolates as a Bifidobacterium species is ruled out because members of this genus tend to be strict anaerobes, produce acetic as well as $\mathrm{L}-(+)$-lactic acid in a 3:2 ratio, have $\mathrm{G}+\mathrm{C}$ contents of 59 to 70 $\mathrm{mol} \%$, and exhibit highly variable morphology (26).

It is believed that the evidence presented herein justifies recognition of the starch-hydrolyzing Lactobacillus strains as belonging to a new species, for which the name Lactoba- 
TABLE 3. Characters useful in differentiating the starch-hydrolyzing bacteria from other Lactobacillus species

\begin{tabular}{|c|c|c|c|c|c|}
\hline \multirow[b]{2}{*}{ Character } & \multicolumn{5}{|c|}{ Organism $^{a}$} \\
\hline & $\begin{array}{c}\text { New } \\
\text { isolates }\end{array}$ & $\begin{array}{l}\text { L. acido- } \\
\text { philus }\end{array}$ & $\begin{array}{l}\text { L. leich- } \\
\text { manii }^{b}\end{array}$ & L. jensenii $i^{b}$ & $\begin{array}{l}\text { L. amylo- } \\
\text { philus }\end{array}$ \\
\hline $\begin{array}{l}\text { Stereoisomer of } \\
\text { lactic acid }\end{array}$ & DL- & DL- & D-(-)- & D-(-)- & $\mathrm{L}-(+)-$ \\
\hline Growth at $15^{\circ} \mathrm{C}$ & - & - & - & - & + \\
\hline Growth at $45^{\circ} \mathrm{C}$ & + & + & + & + & - \\
\hline \multicolumn{6}{|l|}{ Requirement for: } \\
\hline Thiamin & - & - & - & - & - \\
\hline Riboflavin & + & + & - & - & + \\
\hline Pyridoxal & - & - & - & - & - \\
\hline Nicotinic acid & + & + & + & + & + \\
\hline Folic acid & + & + & + & + & + \\
\hline Pantothenic acid & + & + & + & + & + \\
\hline Vitamin $B_{12}$ & - & - & + & + & - \\
\hline $\mathrm{Mol} \% \mathrm{G}+\mathrm{C}$ & 40.4 & 36.7 & 50.8 & 36.1 & 44.4 \\
\hline \multicolumn{6}{|l|}{ Fermentation of: } \\
\hline Amygdalin & $(+)$ & + & + & + & $(+)$ \\
\hline Esculin & $(+)$ & + & + & + & $(+)$ \\
\hline Lactose & (v) & + & + & - & - \\
\hline Mannitol & (v) & - & - & - & - \\
\hline Salicin & $(+)$ & + & + & + & $(+)$ \\
\hline Starch & + & - & - & - & + \\
\hline Sucrose & + & + & + & + & - \\
\hline Trehalose & + & + & + & + & - \\
\hline
\end{tabular}

${ }^{a}$ Symbols: + , Positive reaction or requirement; - , negative reaction or requirement; $(+)$, delayed positive reaction; (v), strain variations.

${ }^{b}$ According to Rogosa (27).

${ }^{c}$ According to Nakamura and Crowell (21).

cillus amylovorus (am.y.lo'vo.rus. Gr. n. amylum starch; L. v. voro to devour; M.L. adj. amylovorus starch-destroying, pertaining to the ability to degrade starch) is proposed. Strain NRRL $\mathrm{B}-4540$ is designated as the type strain. In spite of some minor differences in the sugar fermentation patterns among the strains, the consistently high DNA reassociation values suggest that all of the isolates are members of one species. A description of the type strain follows.

Rods, 1.0 by 3.0 to $5.0 \mu \mathrm{m}$, which occur singly and in short chains. Gram positive and nonmotile. Endospores are not produced.

Agar colonies: white, convex, smooth, circular, entire, opaque.

Broth: turbid, clearing after a few days due to settling of cells.

Acid is produced from cellobiose, fructose, galactose, glucose, maltose, mannose, sucrose, starch, and trehalose. Amygdalin, esculin, and salicin are fermented slowly. Arabinose, gluconate, melezitose, melibiose, raffinose, rhamnose, ribose, sorbitol, and xylose are not fermented. (Some strains slowly ferment lactose and/or mannitol.)

Both L-(+)- and D-(-)-lactic acids are produced.
No gas is produced from glucose or gluconate. Catalase and oxidase are not produced.

Nitrate is not reduced to nitrite.

Growth factor requirements: nicotinic acid, pantothenic acid, folic acid, and riboflavin are essential for growth. Thiamin is not required.

Facultatively anaerobic.

Temperature relations: optimum, 37 to $45^{\circ} \mathrm{C}$. Minimum, 20 to $25^{\circ} \mathrm{C}$. Maximum, between 45 and $50^{\circ} \mathrm{C}$.

DNA: buoyant density, $1.6996 \mathrm{~g} / \mathrm{cm}^{3}$. G+C content, $40.4 \mathrm{~mol} \%$.

Distinctive characteristic: metabolizes starch and produces an extracellular amylolytic enzyme.

Source: cattle waste-corn fermentation.

\section{REPRINT REQUESTS}

Address reprint requests to: Dr. L. K. Nakamura, Northern Regional Research Center, Agricultural Research, Science and Education Administration, U.S. Department of Agriculture, Peoria, IL 61604.

\section{LITERATURE CITED}

1. Buchanan, R. E., and N. E. Gibbons. 1974. Family I. Lactobacillaceae Winslow, Broadhurst, Buchanan, Krumweide, Rogers, and Smith 1917, p. 576. In R. E. 
Buchanan and N. E. Gibbons (ed.), Bergey's manual of determinative bacteriology, 8 th ed. The Williams and Wilkins Co., Baltimore.

2. Carlsson, J. 1973. Simplified gas chromatographic procedure for identification of bacterial metabolic products. Appl. Microbiol. 25:287-289.

3. Deibel, R. H., and H. W. Seeley, Jr. 1974. Family II. Streptococcaceae, fam. nov., p. 490. In R. E. Buchanan and N. E. Gibbons (ed.), Bergey's manual of determinative bacteriology, 8 th ed. The Williams and Wilkins Co., Baltimore.

4. Deibel, R. H., and H. W. Seeley, Jr. 1974. Genus I. Streptococcus Rosenbach 1884, p. 490-509. In R. E. Buchanan and N. E. Gibbons (ed.), Bergey's manual of determinative bacteriology, 8 th ed. The Williams and Wilkins Co., Baltimore.

5. de Man, J. C., M. Rogosa, and M. E. Sharpe. 1960. A medium for the cultivation of lactobacilli. J. Appl. Bacteriol. 23:130-135.

6. Evans, J. B. 1974. Genus IV. Aerococcus, Williams, Hirsch, and Cowan 1953, p. 515-516. In R. E. Buchanan and N. E. Gibbons (ed.), Bergey's manual of determinative bacteriology, 8 th ed. The Williams and Wilkins Co., Baltimore.

7. Ford, J. E., K. D. Perry, and C. A. E. Briggs. 1958. Nutrition of lactic acid bacteria isolated from rumen. J. Gen. Microbiol. 18:273-284.

8. Garvie, E. I. 1974. Genus II. Leuconostoc van Tieghem 1878, p. 510-513. In R. E. Buchanan and N. E. Gibbons (ed.), Bergey's manual of determinative bacteriology, 8th ed. The Williams and Wilkins Co., Baltimore.

9. Gibson, T. 1974. Genus Caryophanon Peshkoff 1939, p. 598. In R. E. Buchanan and N. E. Gibbons (ed.), Bergey's manual of determinative bacteriology, 8 th ed. The Williams and Wilkins Co., Baltimore.

10. Haynes, W. C., L. J. Wickerham, and C. W. Hesseltine. 1955. Maintenance of cultures of industrially important microorganisms. Appl. Microbiol. 3:361-368.

11. Hoffman, W. S. 1937. A rapid photoelectric method for the determination of glucose in blood and urine. J. Biol. Chem. 129:51-55.

12. Hrubant, G. R. 1975. Changes in microbial population during fermentation of feedlot waste with corn. Appl. Microbiol. 30:113-119.

13. Hrubant, G. R., and R. W. Detroy. 1980. Composition and fermentation of feedlot wastes, p. 411-424. In M. Moo-Young and G. J. Farguhar (ed.), Waste treatment and utilization, theory and practice of waste management. Pergamon Press, New York.

14. Johnson, J. L. 1973. Use of nucleic acid homologies in the taxonomy of anaerobic bacteria. Int. J. Syst. Bacteriol. 23:308-315.

15. Kitahara, K. 1974. Genus III. Pediococcus Balcke 1884, p. 513-515. In R. E. Buchanan and N. E. Gibbons (ed.), Bergey's manual of determinative bacteriology, 8th ed. The Williams and Wilkins Co., Baltimore.

16. Latorre-Guzman, B. A., C. I. Kado, and R. E. Kunkee. 1977. Lactobacillus hordniae, a new species from the leafhopper (Hordnia circellata). Int. J. Syst. Bacteriol. 27:362-370.

17. Markov, G. G., and I. G. Ivanov. 1974. Hydroxyapatite column chromatography procedure for isolation of purified DNA. Anal. Biochem. 59:555-563.

18. Marmur, J. 1961. A procedure for the isolation of deoxyribonucleic acid from microorganisms. J. Mol. Biol. 3: 208-218.

19. Mandel, M., and J. Marmur. 1968. Use of ultraviolet absorbance-temperature profile for determining the guanine plus cytosine content of DNA. Methods Enzymol. 12B:195-206.

20. Nakamura, L. K. 1981. In Validation of the publication of new names and new combinations previously effec- tively published outside the IJSB. List No. 6. Int. J. Syst. Bacteriol, vol. 31, in press.

21. Nakamura, L. K., and C. D. Crowell. 1979. Lactobacil lus amylophilus, a new starch-hydrolyzing species from swine waste-corn fermentation. Dev. Ind. Microbiol. 20: 532-540.

22. Reyn, A. 1974. Genus V. Gemella Berger 1960, p. $516-$ 517. In R. E. Buchanan and N. E. Gibbons (ed.), Bergey's manual of determinative bacteriology, 8th ed. The Williams and Wilkins Co., Baltimore.

23. Roberts, E. C., and E. E. Snell. 1946. An improved medium for the microbiological assays with Lactoba. cillus casei. J. Biol. Chem. 163:499-509.

24. Rogosa, M. 1961. Experimental conditions for nitrate reduction by certain strains of the genus Lactobacillus. J. Gen Microbiol. 24:401-408.

25. Rogosa, M. 1970. Characters used in the classification of lactobacilli. Int. J. Syst. Bacteriol. 20:519-533.

26. Rogosa, M. 1974. Genus III. Bifidobacterium Orla-Jensen 1924, p. 669-676. In R. E. Buchanan and N. E. Gibbons (ed.), Bergey's manual of determinative bacteriology, 8th ed. The Williams and Wilkins Co., Baltimore.

27. Rogosa, M. 1974. Genus I. Lactobacillus Beijerinck 1901, p. 576-593. In R. E. Buchanan and N. E. Gibbons (ed.) Bergey's manual of determinative bacteriology, 8 th ed. The Williams and Wilkins Co., Baltimore.

28. Rogosa, M., J. G. Franklin, and K. D. Perry. 1961 Correlation of the vitamin requirements with cultural and biochemical characters of Lactobacillus spp. J. Gen. Microbiol. 25:473-482.

29. Rogosa, M., J. A. Mitchell, and R. F. Wiseman. 1951 A selective medium for the isolation and enumeration of oral and fecal lactobacilli. J. Bacteriol. 62:132-133.

30. Rogosa, M., and M. E. Sharpe. 1960. An approach to the classification of the lactobacilli. J. Appl. Bacteriol. 22:329-340.

31. Rogosa, M., R. F. Wiseman, J. A. Mitchell, M. N. Disraely, and assisted by A. J. Beaman. 1953. Species differentiation of oral lactobacilli from man including descriptions of Lactobacillus salivarius nov. spec. and Lactobacillus cellobiosus nov. spec. J. Bacteriol. 65:681-689.

32. Schildkraut, C. L., J. Marmur, and P. Doty. 1962. Determination of the base composition of deoxyribonucleic acid from its buoyant density in $\mathrm{CsCl}$. J. Mol. Biol. 4:430-443.

33. Seeliger, H. P. R. 1974. Genus Erysipelothrix Rosenbach 1909 , p. 597. In R. E. Buchanan and N. E. Gibbons (ed.), Bergey's manual of determinative bacteriology, 8th ed. The Williams and Wilkins Co., Baltimore.

34. Seeliger, H. P. R., and H. J. Welshimer. 1974. Genus Listeria Pirie 1940, p. 593-596. In R. E. Buchanan and N. E. Gibbons (ed.), Bergey's manual of determinative bacteriology, 8th ed. The Williams and Wilkins Co., Baltimore.

35. Seidler, R. J., and M. Mandel. 1971. Quantitative aspects of deoxyribonucleic acid renaturation: base composition, state of chromosome replication, and polynucleotide homologies. J. Bacteriol. 106:608-614.

36. Sharpe, M. E., T. F. Fryer, and D. C. Smith. 1966. Identification of lactic acid bacteria, p. 65-79. In B. M. Gibbs and F. A. Skinner (ed.), Identification methods for microbiologists. Part A. Academic Press, Inc., New York.

37. Skerman, V. B. D., V. McGowan, and P. H. A. Sneath (ed.). 1980. Approved lists of bacterial names. Int. J. Syst. Bacteriol. 30:225-420.

38. Steele, K. J. 1961. The oxidase reaction as a taxonomic tool. J. Gen. Microbiol. 25:297-306.

39. Taylor, P. M., and W. J. Whelan. 1962. An improved method of fractionating sugars on charcoal. Chem. Ind. Jan. 6, 1962, p. 44-45. 